\title{
MURTAD (PINDAH AGAMA) DALAM KAJIAN HUKUM ISLAM
}

\author{
Abdul Muthalib
}

\author{
Sekolah Tinggi Agama Islam Sumatera Medan \\ Jl. Sambu No. 64, Kota Medan, Sumatera Utara \\ e-mail: abdulmuthalib@staisumatera-medan.ac.id
}

\begin{abstract}
Abstrak: Para ahli hukum sepakat bahwa orang yang menolak perintah Allah dan Rasulnya berarti telah kembali (kiri) dari Islam, entah karena keraguan, penolakan atau ketidaktaatan. Allah SWT dengan sangat jelas dan tegas menyatakan bahwa bagi orang murtad berarti telah menyia-nyiakan perbuatan baiknya dan orang yang meninggal dalam keadaan murtad atau kafir adalah kekal di neraka. Seseorang dianggap telah meninggalkan Islam (Murtad) jika menolak suatu perbuatan yang diwajibkan oleh agama dengan mengingkari kewajiban tersebut dan menganggap dibolehkan untuk tidak memenuhinya. Misalnya, dia tidak melaksanakan shalat, zakat atau haji karena dia meyakini hal-hal tersebut tidak wajib dan dia menolak untuk menjalankan kewajibannya. Seseorang juga dianggap telah meninggalkan Islam jika tidak mau melakukan apa yang diwajibkan oleh hukum Islam dan para ulama menyetujui kewajiban tersebut. Seseorang dianggap kafir jika ia ogah-ogahan atau menolak untuk menjalankan suatu kewajiban padahal ia harus mengetahui kewajiban itu.
\end{abstract}

Kata Kunci: Murtad, Muslim, Hukum Islam

Abstract: The jurists agree that a person who refuses the commandments of Allah and his Messenger means that he has returned (left) from Islam, whether because of doubt, refusal or disobedience. Allah SWT very clearly and firmly states that for apostates it means that he has wasted his good deeds and a person who dies in an apostate or disbelieving state is eternal in hell. A person is considered to have left Islam (Murtad) if he refuses an act which is required by religion by denying this obligation and considers it permissible to not fulfill it. For example, he does not perform prayers, zakat or hajj because he believes these things are not obligatory and he refuses to carry out his obligations. A person is also considered to have left Islam if he does not want to do what is required by Islamic law and the scholars agree on this obligation. a person is considered an infidel if he is reluctant or refuses to carry out an obligation even though he must know that obligation.

Keywords: Apostates, Muslims, Islamic Law

\section{PENDAHULUAN}

Seseorang dianggap keluar dari Islam (Murtad), jika ia menolak perbuatan yang diwajibkan agama dengan cara mengingkari kewajiban tersebut dan menggap boleh sikap tidak menunaikannya. Misalnya tidak menunaikan salat, zakat atau haji karena yakin semua itu tidak wajib ditunaikan dan ia menolak menjalankan kewajibannya.
Seseorang juga dianggap keluar dari Islam apabila ia tidak mau melakukan hal yang diwajibkan hukum Islam dan para ulama sepakat atas kewajiban tersebut. seseorang dianggap kafir apabila ia enggan atau menolak melakukan kewajiban padahal ia pasti mengetahui kewajiban tersebut. (Assagaf, 2014). 
Tidak ada perbedaan pendapat di antara fukaha bahwa setiap hukum yang menyalahi hukum Islam adalah batal, dan tidak wajib dipatuhi. Segala sesuatu yang menyalahi hukum Islam diharamkan atas umat Islam walaupun itu diperintahkan atau dibolehkan oleh pemerintah. Mereka juga sepakat bahwa muslim manapun yang menetapkan selain hukum Allah lalu dengan adanya hukum baru tersebut ia meninggalkan sebahagian atau seluruh hukum yang ditetapkan Allah SWT tanpa ada takwil yang diyakini keabsahannya , maka ia pantas menyandang sifat yang Allah berikan yaitu kafir, zalim dan fasik. Siapa yang berpaling dari hukuman hudud dalam masalah pencurian, qazap atau zina karena mengutamakan hukum buatan manusia, ia kafir secara mutlak. (Moqsith, 2013).

Orang yang membuat hukum baru yang di dalamnya terdapat pengabaian hak, keadilan dan persamaan dan meninggalkan hukum Allah karena alasan lain, tanpa penentangan dan pengingkaran, dianggap berbuat zalim jika di dalamnya tidak terjadi pengabaian hak, persamaan, dan keadilan ia dianggap telah berbuat fasik.

Para fuqaha sepakat bahwa orang yang menolak perintah Allah dan rasulnya berarti telah kembali (keluar) dari Islam, baik itu karena ragu, menolak maupun tidak mau patuh. Allah SWT sangat jelas dan tegas menyatakan bagi para pelaku murtad berarti dia telah menyia-nyiakan amalanamalan kebaikannya dan orang yang mati dalam keadaan murtad atau kafir maka ia kekal di dalam neraka sebagaimana Allah
SWT jelaskan dalam firman-Nya pada surah Al-Baqarah ayat 217 dan juga pada surah Al-Maidah ayat 54.

\section{TAFSIR AHKAM \\ TENTANG MURTAD}

\section{Teks dan Arti ayat}

Surah Al-Baqarah Ayat 217

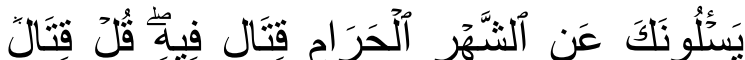

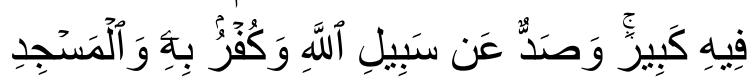

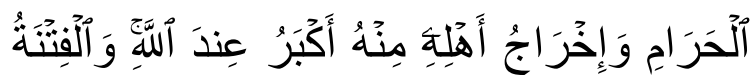

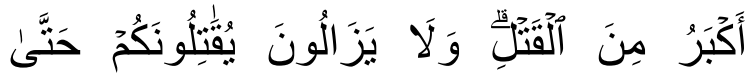

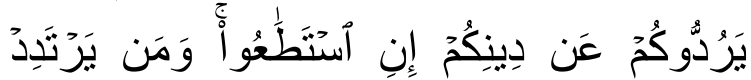

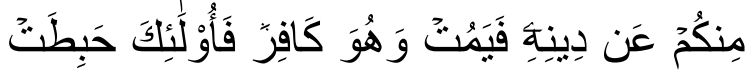

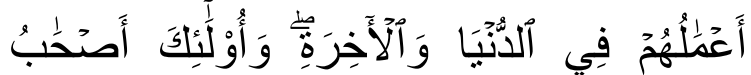

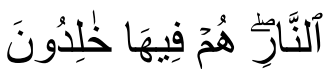

Artinya: Mereka bertanya kepadamu tentang berperang pada bulan Haram. Katakanlah: "Berperang dalam bulan itu adalah dosa besar; tetapi menghalangi (manusia) dari jalan Allah, kafir kepada Allah, (menghalangi masuk) Masjidilharam dan mengusir penduduknya dari sekitarnya, lebih besar (dosanya) di sisi Allah dan berbuat fitnah lebih besar (dosanya) daripada membunuh. Mereka tidak hentihentinya memerangi kamu sampai mereka (dapat) mengembalikan kamu dari agamamu (kepada kekafiran), seandainya mereka sanggup. Barangsiapa yang murtad di antara kamu dari agamanya, lalu dia mati dalam kekafiran, Maka mereka Itulah yang sia-sia amalannya di dunia dan di akhirat, dan mereka Itulah penghuni neraka, mereka kekal di dalamnya.(Q. S. Al-Baqarah: 217) 
Dalam memahami makna kata dan ayat pada surah Al-Baqarah ayat 217

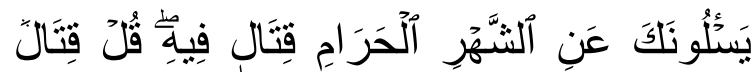

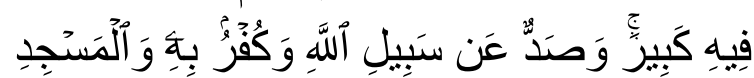

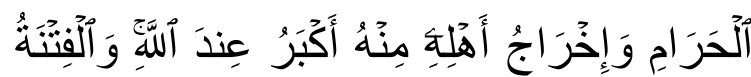

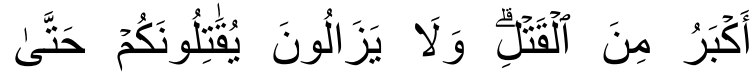

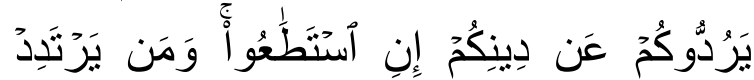

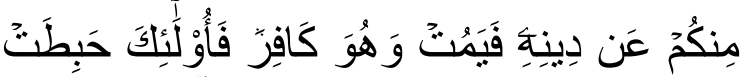

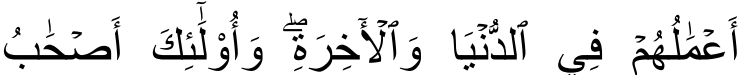

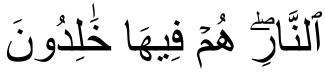

Muhammad Ali Al-Shabuni menjelas-kan makna ayat yaitu:

$$
\begin{aligned}
& \text { يرتدد: أي يرجع, والردة: الرجوع من الإيمان } \\
& \text { إلى الكفر, ويسمى فاعل ذاللك مرتدا }
\end{aligned}
$$

Artinya: Yartadid artinya kembali, dan kata al-Riddah adalah kembali dari iman kepada kafir dan isim failnya adalah Murtad. (AlShabuni, 1990).

قال الراغب: الإرتداد والردة: الرجوع في الطريق الذي جاء منه. لكن الردة تختص بالكفر , والإرتدد بيتعمل فيه وفي غيره قال تعالى:(من يرتد منكم عن دينه) و هو الرجوع من الإسلام إلى الكفر.

Artinya: "Berkata Imam Al-Ragib alAsfahaniy: al-irtidad dan al-Riddah yaitu kembali setelah berjalan pulang, akan tetapi maksud al-Riddah disini adalah kafir, kata al-irtidad dipergunakan maknanya untuk kafir atau makna lainnya. firman Allah Swt: Barang siapa yang murtad diantara kamu dari agamanya yaitu kembali dari Islam kepada kekufuran.” (Al-Suyuthi, 1990).

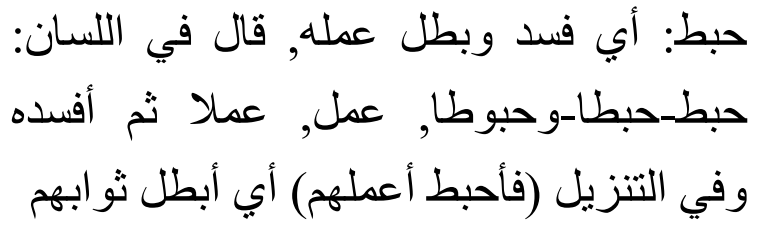

Artinya: "Habitho: yaitu rusak dan batal amalannya. habitho-habthon-habuthon, 'amila-'amalan, kemudian merusaknya, sebagaimana kalimat di dalam Al-Quran (faahbitho a'malahum) maksudnya telah hilang pahala mereka." (Al-Suyuthi, 2003).

Abi Bakar Jabir Al-Jazairi menjelaskan dalam Tafsirnya Aysar AlTafasir li kalam Al-'Aliy Al-Kabir:

من يرتد عن دينه ولم يتب بأن مات كافر ا فإن

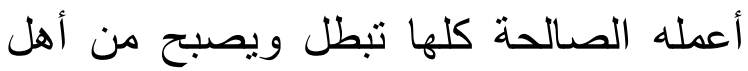
النار الخالدين فيها أبدا

Artinya: "Siapa yang murtad dari Agama Islam, dan tidak bertaubat maka matinya dalam keadaan kafir, maka seluruh amal ibadahnya terhapus, jadilah ia penduduk neraka yang kekal di dalamnya." (Aljazairi, 1990).

Ayat 217 Surah Al-Baqarah sering digunakan oleh pengkaji Barat dalam usaha mereka untuk memburuk Islam dalam hal berkaitan peperangan. Ayat ini berkait dengan peristiwa di Nakhlah yang dipimpin oleh Abdullah bin Jahsy. (Al-Naisaburi, 1990). Imam Ibnu Katsir dalam kitab Tafsirnya menjelaskan akan sebab turunnya ayat tersebut:

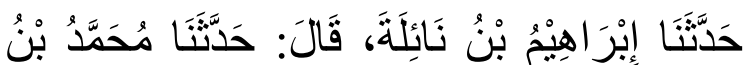

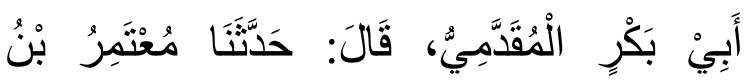

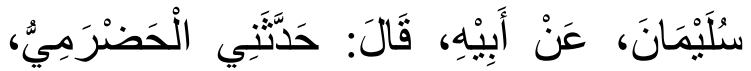

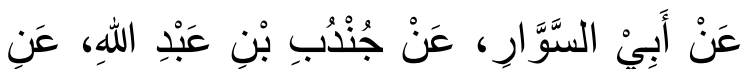




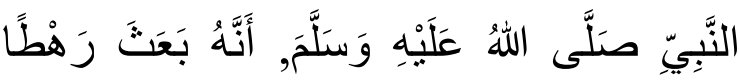

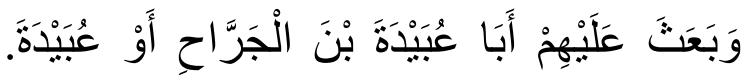

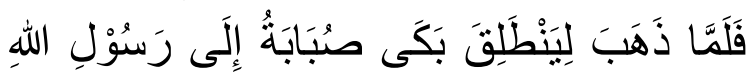

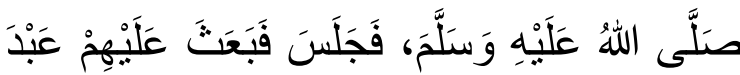

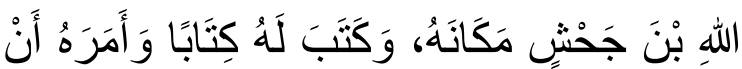

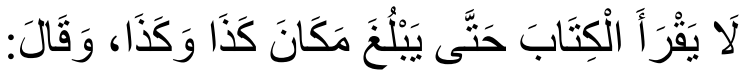

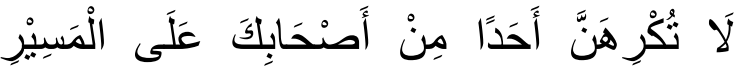

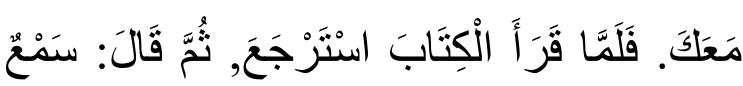
وَطَاعَةُّ لِلَّهِ وَرَسُوْلِهِ. فَخَبَّرَ هُمُ الْخَبَرَ, وَقَرَأَ

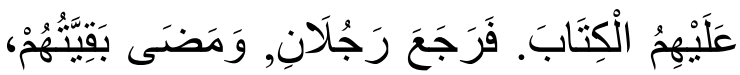

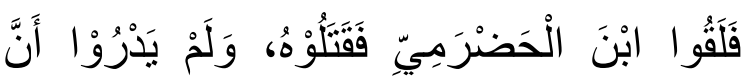

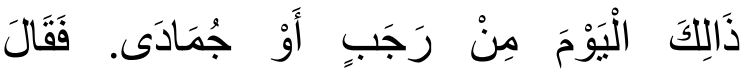

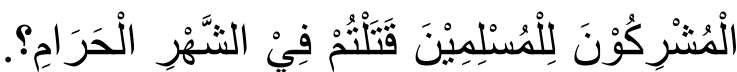

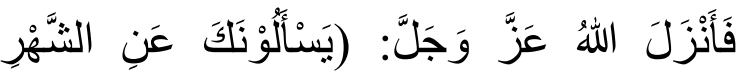

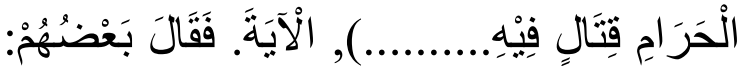

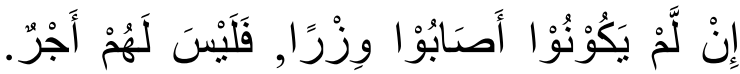

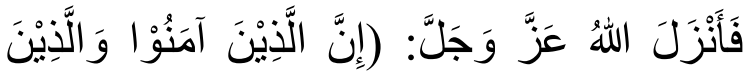

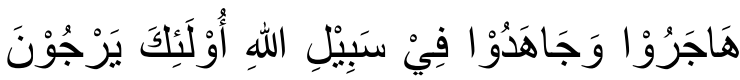

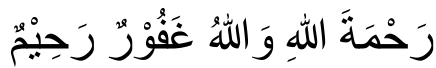

Artinya: "Ibrâhîm bin Nâilah telah bercerita kepada kami (kepada ath-Thabarânî), dia (Ibrâhîm bin Nâilah) berkata: "Muhammad bin Abî Bakr al-Muqaddamŷ telah bercerita kepada kami (kepada Ibrâhîm bin Nâilah), dia (Muhammad bin Abî Bakr alMuqaddamŷ) berkata: "Mu'tamir bin Sulaimân telah bercerita kepada kami (kepada Muhammad bin Abî Bakr alMuqaddamŷ), dari bapaknya (namanya yaitu: Sulaimân bin Tharkhân dia (Sulaimân bin Tharkhân) berkata: "Hadhramŷ telah bercerita kepada saya (kepada Sulaimân bin Tharkhân), dari Abû as-Saŵâr dari Jundub bin 'Abdillâh dari
Nabi Saw; bahwasannya beliau SAW. mengutus satu Pasukan, dan Abû 'Ubaidah bin al-Jarrâh atau 'Ubaidah juga diutus oleh beliau Saw. dalam Pasukan tersebut. Ketika beliau Saw. keluar untuk berangkat, tibatiba Shubâbah menangis dan mengadu kepada Rasûlullâh Saw. Kemudian beliau Saw. duduk dan mengutus 'Abdullâh bin Jahsy menggantikan posisi beliau Saw. untuk memimpin Pasukan Kaum Muslimîn. Setelah itu beliau Saw. menulis sepucuk Surat, dan menyuruh 'Abdullâh bin Jahsy agar tidak membaca Surat yang beliau Saw. tulis, hingga 'Abdullâh bin Jahsy tiba (sampai) di tempat ini dan ini. Setelah 'Abdullâh bin Jahsy tiba (sampai) di tempat yang diperintahkan Nabi Saw; kemudian ia ('Abdullâh bin Jahsy) membaca Surat tersebut seraya berkata: "Dalam perjalanan kalian (dan di manapun kalian berada), janganlah kalian membenci (maupun membunuh) para Sahabat (Nabi Saw)". Dan ketika 'Abdullâh bin Jahsy telah membaca Surat tersebut, kemudian ia ('Abdullâh bin Jahsy) berkata: "Kepatuhan dan ketaatan bagi Allâh Swt. dan Rasûl-Nya". Maka kemudian 'Abdullâh bin Jahsy mengabarkan kabar dari Rasûlullâh Saw. Dan membacakan Surat tersebut kepada mereka (kapada Kaum Muslimîn setempat). Kemudian dua orang lelaki dari Pasukan Kaum Muslimîn yang diutus Nabi Saw. kembali ke rumah, sedangkan yang lain tetap melanjutkan perjalanan mereka (perjalanan pasukan kaum muslimin) ke tempat-tempat lain yang diperintahkan Nabi Saw. Lalu di tengah perjalanan mereka (pasukan kaum muslimin) bertemu dengan pasukan kaum musyrikin yang dipimpin 
oleh 'Amrû bin al-Hadhramŷ, peperangan pun berkobar, dan akhirnya Pasukan Kaum Muslimîn dapat membunuh 'Amrû bin alHadhramŷ (pemimpin pasukan kaum Musyrikîn). Sedangkan mereka (Pasukan Kaum Muslimîn) tidak mengetahui apakah pada hari itu di bulan Rajab atau di bulan Jumadil akhir...?. Lalu berkatalah kaum musyrikîn kepada kaum muslimîn: "Apakah kalian (kaum muslimîn) berperang di bulan-bulan Harâm, Maka Allâh Swt. menurunkan Surat al-Baqarah, Ayat: 217. (Katsir, 2000).

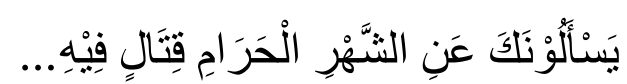

Artinya: "Mereka (Kaum Musyrikîn) bertanya kepadamu (kepada Nabi Muhammad Saw. dan Kaum Muslimîn) tentang berperang pada bulan haram...". "(Rasûlullâh Saw. melanjutkan): "Maka berkatalah sebagian Kaum Muslimîn: "Peperangan mereka (Peperangan Pasukan Kaum Muslimin) dengan Pasukan Kaum Musyrikîn yang dipimpin oleh 'Amrû bin al-Hadhramŷ itu mungkin tidak berdosa, akan tetapi mereka (Pasukan Kaum Muslimin) juga tidak mendapatkan Pahala". Maka Allâh Swt. menurunkan Surat alBaqarah, Ayat: 218:

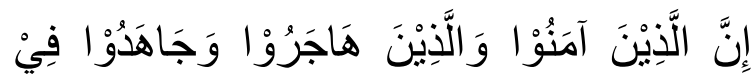

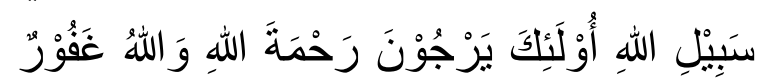
رَحِيْمِ

Artinya: "Sesungguhnya orang-orang yang Beriman, orang-orang yang Berhijrah dan Berjihad di jalan Allâh, mereka itu mengharapkan rahmat Allâh, dan Allâh Maha Pengampun lagi Maha Penyayang".

\section{Seseorang Terindikasi Murtad}

Riddah adalah memutus keislaman (orangnya disebut murtad) degan kekufuran. Dalam hal ini Riddah terbagi tiga:

- Riddah Qauliyah (perkataan) seperti mencaci maki Allah, para Nabi atau Islam, walaupun dalam keadaan marah.

- Riddah Fi'liyyah (Perbuatan) seperti melempar mushaf AlQuran ketempat-tempat kotor dan juga seperti menginjak mushaf.

- Riddah Qalbiyyah (hati) seperti meyakini bahwa Allah adalah benda atau ruh, meyakini bahwa Allah duduk di atas 'arasy atau menempati langit atau meyakini bahwa dzat Allah berada disemua tempat. Allah Ta'ala berfirman:

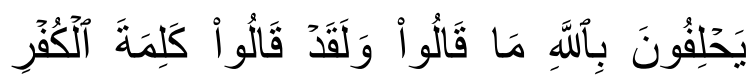

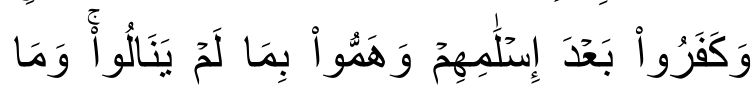

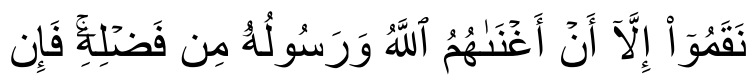

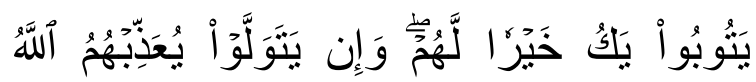

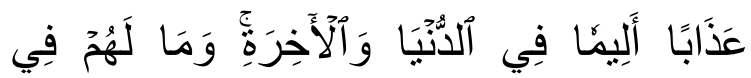

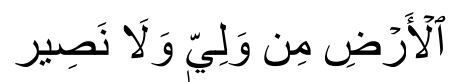
Artinya: "Mereka (orang-orang munafik itu) bersumpah dengan (nama) Allah, bahwa mereka tidak mengatakan (sesuatu yang menyakitimu). Sesungguhnya mereka telah mengucapkan Perkataan kekafiran, dan telah menjadi kafir sesudah Islam dan mengingini apa yang mereka tidak dapat mencapainya, dan mereka tidak mencela (Allah dan Rasul-Nya), kecuali karena 
Allah dan Rasul-Nya telah melimpahkan karunia-Nya kepada mereka. Maka jika mereka bertaubat, itu adalah lebih baik bagi mereka, dan jika mereka berpaling, niscaya Allah akan mengazab mereka dengan azab yang pedih di dunia dan akhirat; dan mereka sekali-kali tidaklah mempunyai pelindung dan tidak (pula) penolong di muka bumi." (Q.S. Al-Taubah: 74)

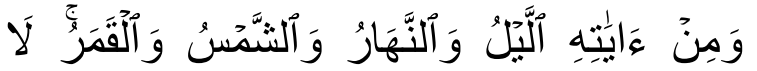

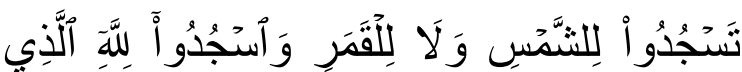

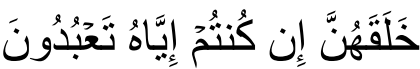

Artinya: "dan di antara tanda-tanda kekuasaan-Nya ialah malam, siang, matahari dan bulan. janganlah sembah matahari maupun bulan, tapi sembahlah Allah yang menciptakannya, jika ialah yang kamu hendak sembah." (Fussilat ayat 37)

Seorang dapat dianggap murtad atau keluar dari Islam karena dengan, perkataannnya, perbutannya maupun karena i’tiqadnya. Al-Imam Zainuddin Bin Abdul 'Aziz al-Malibari (Al-Malibari, 1992) menjelaskan Murtad merupakan bentuk kekafiran terburuk dan menghapus semua amal kebaikan sebelumnya. Dalam terminologi syariah Islam, murtad adalah pemutusan hubungan dengan Islam dalam bentuk niat yang dilakukan saat ini atau yang akan datang atau dalam bentuk perkataan atau perbuatan dengan keyakinan pada perbuatan atau perkataan itu atau bersamaan atau disertai kesengajaan atau penghinaan yang dilakukan oleh seorang muslim (mukallaf) dengan kemauan sendiri. Murtad tidak terjadi apabila pemutusan keislaman itu dilakukan oleh anak-anak, orang gila atau orang yang dipaksa apabila hatinya tetap beriman. Juga tidak terjadi murtad apabila bersamaan dengan sesuatu yang dikecualikan dari kemurtadan seperti tergelincir lidah (keceplosan), bercerita tentang kekufuran atau karena takut. seorang dapat menjadi murtad dengan beberapa sebab yang beliau utarakan di antaranya:

و اعلم أن من أنواعها: أن يعزم مكلف مختار على الكفر في زمن قريب أو بعيد, أو يتردد فيه, أو يعلقه باللسان أو القلب على شيئ ولو محالا عقليا , فيكفر حالا , أو يعتقد ما يوجيه

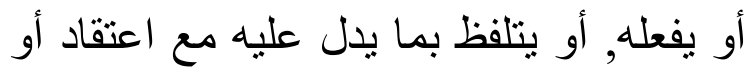
عناد أو استهزاء كأن يعتقد قدم العالم أو أو الروح أو حدوث الصانع, أو ينفي ما هو ثابت

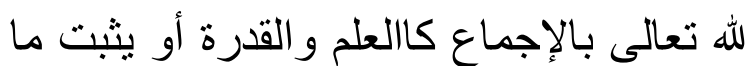
هو منفي عنه بالإجماع كاللون أو بيعتق وجوب غير واجب كصلاة سادسة وصوم غير رمضان, أو يشك في تكفير اليهود و النصارى, وكأن يسجد لمخلوق كصنم و شمس, أو يمش إلى الكنائس مع أهلها بزيهم عن الزنانير وغير ها. وكأن ينكر نبوة نبي

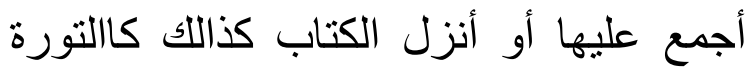
والإنجيل والزبور وصحف إبراهيم أو أيات من القرأن مجمعا عليها كالمعوذنتين, أو ينكر وجوب و اجب, أو ندب مندوب أو تحريم حرام أو تحليل حلال أجمع عليها, أو ينكر إعجاز

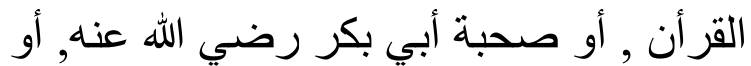
البعث, أو الجنة أو النار, أو كأن يكذب نبيا, أو أو يستخف به أو بملك أو بسبهما, أو بقذف أو 


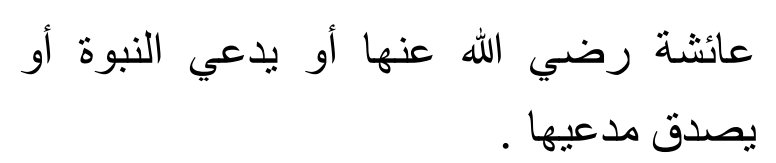

Artinya: "Dan ketahuilah bahwa termasuk daripada katagori murtad yaitu mengazamkan seorang mukallaf dengan memilh kafir, dalam waktu sebentar atau lama atau timbulnya keraguan pada masa itu. dengan lidah atau hati pada sesuatu, walaupun keyakinannya mustahil diterima secara akal, maka hal itu menjadikannya kafir atau melafazkan dengan menunjukkan kerusakan keyakinannya, atau membantah dari hukum syara', atau memperolok-olok, seperti iya yakini akan qodimnya alam, atau ruh, atau dia yakini bahwa Allah Swt bersifat baharu, atau menafikan sesuatu yang telah tsabit bagi Allah Swt secara ijma' seperti ilmu dan qudrat Allah Swt. atau mentsabitkan sesuatu yang di nafikan kepada Allah Swt, atau meyakini suatu kewajiban yang tidak wajib, salat enam waktu, kewajiban berpuasa selain dibulan Ramadhan, atau meragukan tentang kekufuran orang-orang Yahudi dan Nasrani, Dan menyembah kepada makhluk seperti patung dan matahari atau berjalan ke gereja bersama jamaah gereja dengan seragam kebesarannya dan lainnya

Juga disebut murtad orang yang mengingkari para Nabi yang telah ijmak ulama akan kenabiannnya atau mengingkari akan turunnya Al-Kitab seperti Taurat, Injil, Zabur, suhup Nabi Ibrahim atau mengingkari akan ayat-ayat Al-Qur'an, seperti berkumpulnya dua ayat mu'awwizat, atau mengingkari perintah yang wajib, sunnah, yang haram dan yang halal yang telah ijma' ulama terhadapnya. Termasuk indikasi kemurtadan adalah mengingkari akan kemukjizatan Al-Qur'an, atau mengingkari sahabat utama Nabi Abu Bakar rodiyallohu 'anhu, atau mengingkari akan tejadinya hari berbangkit, mengingkari akan adanya syurga dan neraka. Atau mendustakan kenabian seorang Nabi yang di utus. atau meremehkan dan menghinakannya, Atau menuduh istri Nabi 'Aisyah berselingkuh dengan Sofwan Bin Mu'atthol, Begitu juga murtad bagi orang yang mengaku nabi atau mengakui akan adanya Nabi setelah di utusnya Baginda Rasul Saw.

Seseorang juga dianggap keluar dari Islam (murtad) karena mengucapkan perkataan yang secara tabiat membuatnya kafir atau menuntut menjadikannya kafir. Misalnya ia mengingkari sifat ketuhanan, dan tidak mengakui adanya Tuhan. Atau mengingkari keesaan-Nya, Menyatakan bahwa Allah mempunyai sekutu, teman, istri atau anak. Mengaku sebagai Nabi, atau membenarkan orang yang mengaku Nabi, mengingkari para nabi, malaikat atau salah satu dari mereka. Begitu juga jika seseorang mengingkari Al-Qur'an atau sebagian isinya seperti menyatakan pendapat bahwa ayat ini sudah tidak relevan untuk dipergunakan dan diterapkan pada saat sekarang ini, atau mengingkari hari kiamat, mengingkari Islam, atau dua kalimat syahadat, menyatakan lepas dari Islam atau menyatakan bahwa hukum Islam bukan untuk membina hubungan antara perseorangan dan masyarakat. Ia juga dianggap keluar dari Islam jika ia 
menyatakan bahwa para hakim dan yang dihukumi hukum-hukumnya tidak wajib diterapkan dalam kondisi dan masalah apapun, mengatakan bahwa semua atau sebahagian hukum Islam adalah hukum yang terbatas untuk masa tertentu. Atau mengatakan bahwa hukum Islam sudah tidak layak diberlakukan pada masa sekarang dan hukum konvensional lainnya lebih baik dari hukum islam. (Muhammad, Ahsin Sakho, 2007).

Seseorang bisa dianggap kembali (keluar) dari Islam jika ia memiliki keyakinan yang menafikan Islam. Misalnya, keyakinan mengenai qidam-nya (kekekalan) alam, tidak ada Zat yang mencipta, atau adanya pencipta baru. Begitu juga halnya dengan keyakinan bersatunya makhluk dengan khalik atau titipan ruh, keyakinan bahwa Al-Qur'an datang dari selain Allah dan Muhammad Saw adalah pembohong, keyakinan bahwa Ali adalah Tuhan atau Rasul, dan keyakinan-keyakinan lain yang menafikkan Al-Qur'an dan hadits. Begitu juga keyakinan bahwa Hukum Islam sudah tidak layak untuk diterapkan pada masa kini, keyakinan bahwa penerapan Hukum Islam adalah sebab keterbelakangan dan kemunduran kaum muslim,atau keyakinan bahwa umat Islam tidak layak lagi terikat hukum Islam dan harus berpedoman kepada hukum-hukum konvensional.

\section{Hukuman Bagi Pelaku Murtad}

Keluar dari Islam melalui perbuatan bisa terjadi dengan melakukan perbuatan yang dilarang oleh Islam dan pelaku menganggap hukum melakukannya adalah halal. hal ini bisa ia lakukan dengan sengaja atau dengan menghina Islam, Dengan menganggap remeh atau dengan memperlihatkan kesombongan. Misalnya sujud kepada berhala, matahari, bulan, atau planet manapun, mencampakkan mushaf dan kitab-kitab hadits ke kotoran, menginjaknya, memandang hina dan rendah ajaran yang ada di dalamnya atau mengingkarinya. Maka Islam tidak dapat mentoleril pelaku penghinaan seperti itu. Maka dalam Islam orang yang menghinakan seperti itu di hukum murtad dan bagi pelaku murtad di eksekusi mati sebab kemurtadannya. sebagaimana Sabda Nabi SAW:

عن إين عباس رضي الله عنه قال: قال رسول الله

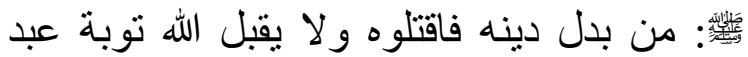
كفر بعد إسلامه أي مادام مصر ا على كفره )رو اه

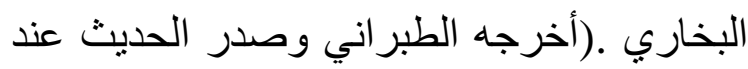
البخاري عن إبن عباس) هذا الحديث حسن

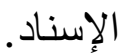

Artinya: "Siapa yang menukar atau mengganti agamanya(Islam), maka bunuhlah ia, Karena Allah Swt tidak menerima taubat seorang hamba yang kafir setelah ia Islam selama ia bertahan dalam kekafirannya."

Juga Sabda Nabi Saw dihukum bunuh bagi pelaku murtad:

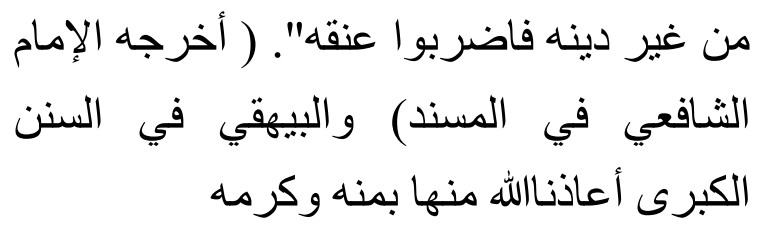

Artinya: Siapa yang mengganti agamanya (Murtad) Maka penggallah lehernya. 
Nabi SAW Bersabda:

عن أبي مسعود رضي الله عنه قال: قال رسول الله

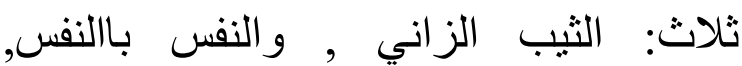
والتارك لدينه المفارق للجماعة) رواه البخاري ومسلم .والتارك لدينه المفارق للجماعة : أي الذي فارق جماعة المسلمين وخرج عن جملتهم وانفرد عن زمرتهم بالردة التي هي قطع الإسلام قولا أو فعلا أو إعتقادا

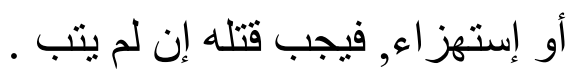

Artinya: “Dari Abi mas'ud Semoga Allah Meridoinya ia berkata: Telah bersabda Nabi SAW: Tidak halal darah seseorang kecuali karena salah satu dari tiga perkara: pertama: Janda yang berzina, membunuh seorang muslim, meninggalkan agama (Murtad) berpisah dari jamaah." (Al-Bukhari, 1978).

Al-Imam Sa'ad al-din Mas'ud Bin Umar Bin abdullah menjelaskan akan والتارك لدينه maksudnya memisahkan diri dari jamaah muslimin, keluar dari kelompok mereka, berpisah dari komunitas muslimin dengan murtad yaitu memutuskan keyakinan dengan agama Islam baik dengan perkataannya, perbuatan, keyakinan maupun dengan memperolok-oloknya, maka wajib mengeksekusi mati jika dia tidak mau bertaubat dari kemurtadannya. (Mas'ud, 2004).

Abdul Qadir Audah di dalam kitabnya al-Tasyri' al-jinai al-Islamiy Muqaranan bi al-Qanun al-wadh'i:

$$
\text { بعتبر المرتد مهدار الدم من وجهين : }
$$

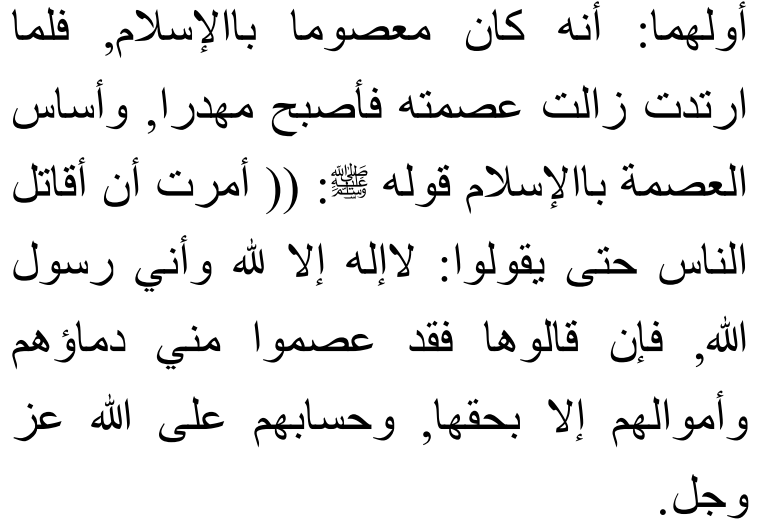

ثانيهـا: أن عقوبة المرتد في الثربعة القتل

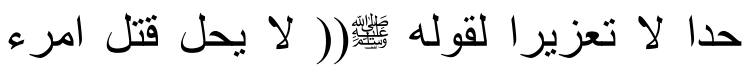
مسلم إلا بإحدى ثلاث: كفر بعد إيمان, وزنا بعد إحصان وقتل نفس بغير نفس)) ولقوله

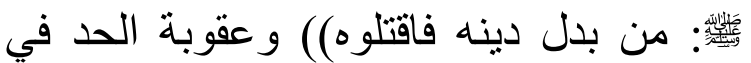
الثريعة لايجوز العفو عنها ولا تأخير ها.

ويشترط الفقهاء قبل الحكم بعقوبة القتل على المرتد أن بستتاب ويعرض عليه الإسلام من جديد, فإن لم يتب قتل حدا .

Artinya: Dinyatakan halal darahnya bagi orang yang murtad atas dua macam: Salah satunya adalah: Bahwasannya ia maksum(terjaga) dengan keislamannya, ketika ia menjadi murtad maka hilang kemaksumannya (terpelihara) karenanya halal darahnya, dan prinsip kemaksuman dalam Islam, sebagaimana sabda Nabi Saw : Aku telah diperintahkan untuk memerangi manusia sehingga mereka mengucakan: Tiada Tuhan yang di sembah selain Allah, dan bahwasannya aku adalah utusan Allah. Maka jika mereka mengucapkannya sesungguhnya telah terjaga daripadaku darah, harta dan hak mereka, Meraka akan dihisab Allah Ta'ala. (Audah, 2009) 
Yang kedua: Bahwasannya sanksi bagi pelaku murtad menurut Syariat adalah dibunuh sebagai hukuman had, bukan hukuman ta'zir. Sebagaimana Sabda Nabi Saw: Tidak halal membunuh seorang muslim kecuali dengan tiga sebab: pertama, kafir setelah beriman (Murtad), kedua berzina setelah menikah. Dan yang ketiga membunuh muslim yang lain. sebagaimana Sabda Nabi Saw: (Barang siapa mengganti Agamanya maka bunuhlah ia. Dan hukuman Had menurut syariat tidak dapat dimaafkan dan tidak boleh di akhirkan vonisnya.

Para fuqaha memberikan syarat sebelum eksekusi hukuman bunuh bagi pelaku murtad, Bahwa ia diminta untuk bertaubat, dan kembali kepada Islam dengan memperbaharui keimanannya, jika ia tidak mau bertaubat dibunuh sebagai hukuman had.

\section{Hikmah Dihukum Had (Bunuh) Bagi Pelaku Murtad}

Agama Islam adalah agama yang syamil, kamil universal, dapat diterima oleh akal sebagai syariat yang samawi, yang diturunkan sebagai wahyu yang suci dari Nabi yang suci, dengan ketinggian serta kemuliaan syariat dan si pembawa syariat menjadikan Islam itu tinggi dan idak ada yang lebih tinggi dan mulia darinya. Sebagaimana beliau bersabda: الإسلام يعلواو لا Agama Islam itu tinggi dan tidak ada yang lebih tinggi darinya.

Tentunya syariat Islam yang di turunkan oleh Allah SWT melalui perantara Rasulnya akan dijaga terus kemurniaannya sampai hari kiamat terbukti tetap ada yang membelanya. Ketika Islam dihina, ketika Al-Quran di remehkan, ketika ulama dihinakan ketika Nabi-Nya didiskreditkan, bahkan pembelaan umat dalam hal ini tidak tanggung-tanggung sampai titik darah penghabisan artinya siap bertaruh nyawa sebagai jihad di jalan Allah SWT. Umat Islam tetap membelanya karena itu adalah bahagian keyakinan umat Islam yang tidak dapat dianggap remeh bagi siapapun pelakunya. karena ada ketentuan dalam Islam untuk menghukum bagi pelaku yang meremehkan Islam dengan sebab keluar dari Agama Islam (Murtad) yaitu hukuman mati.

Allah SWT menjelaskan tentang kemuliaan Islam dan umat Islam dilarang untuk menghinakan diri, karena Islam itu sendiri sebagai agama yang di anut sangat tinggi dan mulia akan kedudukannya, karenanya tidak boleh dianggap remeh dengan cara murtad dari Islam, kemudian kembali ke Islam lalu murtad kembali, baik karena sebab ekonomi, perkawinan dan sebaginya.

Allah Swt berfirman: ولا تهنواو لا تحزنو "Janganlah kamu bersikap lemah, dan janganlah (pula) kamu bersedih hati, Padahal kamulah orang-orang yang paling Tinggi (derajatnya), jika kamu orang-orang yang beriman.” (Q.S Ali Imran 139)

Ditetapkannya hukuman mati (Had) bagi pelaku murtad untuk meminimalisir dan membuat efek jera bagi orang yang murtad dengan sebab berubah keyakinanya ataupun dengan sebab istihza'. Belakangan ini banyak sekali kita lihat dan baca 
bagaimana kelompok-kelompok pembenci Islam baik dari kalangan kelompok lantardho (Yahudi dan Nasrani) maupun dari kelompok munafikin yang seenaknya meremehkan akan Islam seperti istihza' dengan Al-Qur'an membaca Al-Qur'an dengan tanpa mempergunakan kaidahkaidah Alquran itu sendiri seperti kita dengar bacaan Alquran dengan langgam kedaerahan, seperti langgam jawa, ketika acara Nasional Isra'dan mi'raj Nabi Muhammad Saw di istana Negara, sang Qari membaca Al-Qur'an dengan langgam jawa yang menyalahi akan perintah Baginda Rasul Saw. Padahal Nabi Muhammad Saw memerintahkan untuk membaca Al-Qur'an dengan langgam Arab إقرأو القرأن إن beliau bersabda: artinya: "Bacalah Alquran dengan langgam arab."

kelompok jaringan Islam liberal atau jaringan Islam nusantara, kaidah-kaidah Islam ingin dirusak, dipreteli, oleh mereka. Jika tujuan membaca AlQuran tersebut dalam rangka istihza' maka hukumnya murtad sebagaimana sabda Baginda rasul SAW: من استهزء بالقرأن فقد كفر siapa yang memperolok-olok Alquran maka sunguh ia telah kafir. oleh karenanya hikmah di hukum bunuh bagi pelaku murtad, agar berhati-hati terhadap pelecehan akan Syariat Islam sebagai agama yang di akui oleh Allah SWT sebagaimana Firman-Nya: Sesungguhnya Agama yang diakui oleh Allah Swt adalah agama Islam." Oleh karenanya seorang harus berhati-hati di dalam perbuatan atau perkataannya agar jangan sampai Agama
Islam sebagai keyakinan Umat terhinakan dengan perbuatan dan perkataan seseorang, Padahal dalam Islam mempunyai batasanbatasan syariat yang sangat dipelihara dan dihormati. (Al-Andalusiy, 1989).

\section{SIMPULAN}

Sesuatu yang paling berbahaya bagi diri seorang muslim adalah menganggap remeh terhadap agamanya apalagi pelakunya tidak mengetahui bahwa dengan sebab keyakinannya yang melenceng, ataupun ucapannya yang meremehkan Islam ataupun dengan perbuatannya yang berpaham liberal akibat terkena penyakit virus sepilis (sekelarisme, pluralisme dan liberalisme) Dari akibat kebebasan seperti itu tanpa ada batas dengan berpaham sepilis tersebut dapat menggugurkan keimanannya dan keyakinannya terhadap Islam, dan tanpa disadarinya akibat kebebasan yang tanpa batas ia menjadi murtad, benarlah apa كاد الفقر أن بكون كفرا:yang disabdakan Nabi kefakiran, kemiskinan akan ilmu Agama dan kedangkalan aqidah dapat menyebabkan seseorang itu menjadi kafir. Jika dia tidak bertaubat dari dosa-dosa sepilis tersebut maka ia mati dalam keadaan kafir dan menjadi penduduk neraka yang kekal di dalamnya, wal'iyazu billah, semoga kita berlindung dari hal tersebut.

\section{DAFTAR PUSTAKA}

Al-Andalusiy, M. I. H. (1989). Tafsir alBahr Al-Muhit. Dar Ihya' al-Turats alArabiy.

Al-Bukhari, M. (1978). Sahih al-Bukhari. Dar Ul-Hadith. 
Al-jazairi, A. B. J. (1990). Aysar Al-Tafasir

li kalam Al-'Aliy Al-Kabir.

Saudiarabia.

Al-Malibari, Z. B. A. A.-A. (1992). Irsyad al-Ibad ila sabili al-Rasyad. Dar Kutb Ilmiyah.

Al-Naisaburi, A. al-H. A. B. A. (1990). Asbab al-Nuzul. Dar Kutb Ilmiyah.

Al-Shabuni, M. A. (1990). Rawai'i albayan Tafsir ayat al-ahkam min alQuran. Dar al-bayan al-Arabiy.

Al-Suyuthi, J. (1990). Tafsir al-Jalalain. Dar As-Salam.

Al-Suyuthi, J. (2003). al-dur al-Mantsur fi tafsir bi al-ma'sur. Markaz al-Hijr li al-buhuts al-Dirasat al-arabiyah alIslamiyyah.

Assagaf, J. (2014). Kontekstualisasi hukum murtad dalam perspektif sejarah sosial hadis. Ijtihad: Jurnal Wacana Hukum Islam Dan Kemanusiaan, 14(1), 2139.

Audah, A. Q. (2009). al-Tasyri' al-jina'i alIslamiy muqaranan bi al-Qanun alwadh 'i (Juz II). Dar-Al-Hadits.

Katsir, I. (2000). Tafsir Ibnu Katsir. In Jld. II, Beirut: Dar al-Fikr, tt.

Mas'ud, S. al-din B. U. B. abdullah. (2004). Syarah al-Taftazani 'ala al-hadits alarba'in al-Nawawiyah. Dar Kutb Ilmiyah.

Moqsith, A. (2013). Tafsir atas hukum murtad dalam Islam. AHKAM: Jurnal Ilmu Syariah, 13(2).

Muhammad, Ahsin Sakho, et. a. (eds). (2007). Ensiklopedi Hukum Pidana Islam. Kharisma Ilmu. 